Karolina Pospiszil

UNIWERSYTET ŚLĄSKI W KATOWICACH

e-mail: pospiszil@gmail.com

(iD http://orcid.org/0000-0001-7622-5394

\title{
"Arystokraci nędzy”, czyli Kazimiery Alberti opowieść o odrzuconych
}

\section{Abstract}

\section{„The Aristocracy of the Poor",}

\section{or Kazimiera Alberti's narrative about the Rejected}

The paper focuses on an undercurrent analysis of social problems present in almost all Kazimiera Alberti's work written in an interwar period. A kind of "hierarchy" of people suffering from social, economic, ethnic and gender inequality is evident in Alberti's works. This "hierarchy" could be considered as hell circles, although a gradation of pain and misery depends on a level of social rejection, not on committed sins. Alberti puts cultural and ethnic hybrids in the deepest circle of hell - those people are perceived as others/aliens (and often not as human beings) by both (or more) cultures/communities, they are "made" from.

Key words: Kazimiera Alberti, Polish interwar literature, the Other, rejection, social issues, cultural hybrids

Słowa kluczowe: Kazimiera Alberti, polska literatura międzywojenna, obcy/inny, odrzucenie, problemy społeczne, hybrydy kulturowe 
I w noc ogłuchłą krzyk nasz wyleci ogromny...

Często w swojej twórczości pochylała się nad zapomnianymi, zepchniętymi na marginesy społecznej świadomości ludźmi, opisywała z naturalistyczną precyzją i społecznikowskim zacięciem miejską i wiejską nędzę, dawała głos niemym i sama w ciągu niespełna kilku, kilkunastu lat została niemal zupełnie zapomniana - mimo wielu kontrowersji, jakie kiedyś wzbudzała. Kazimiera Alberti, bo o niej mowa, była jedną z wielu znanych, ale raczej drugorzędnych pisarek dwudziestolecia międzywojennego. I choć nie wywarła dużego wpływu na rozwój literatury polskiej, nie można jej odmówić świetnego zmysłu obserwacji, co najmniej kilku udanych poetyckich i prozatorskich prób, wielu świetnych przekładów z czeskiego i bułgarskiego oraz ogromnej pracy włożonej w rozwój życia kulturalnego na Podbeskidziu.

Pisarka, dziś znana tylko grupce literaturoznawców i pasjonatów, w okresie międzywojennym cieszyła się dość dużą popularnością, o czym świadczą setki recenzji, artykułów oraz polemik prasowych wycinanych i wklejanych przez samą autorkę do pięciu grubych zeszytów (ponad sześćset stron!) ${ }^{1}$. Pozostaje nierozwiązaną kwestią, czy to „zbieractwo” było wynikiem strachu przed zapomnieniem, skutkiem egzaltacji młodej literatki, czy też efektem swoistego „zacięcia” dokumentarystki. Znamienne, że w tych zeszytach znajdziemy niemal jedynie świadectwa recepcji (pisarka zbierała teksty pochlebne, jak i bardzo krytyczne), ale - poza małymi wyjątkami - nie ma w nich twórczości autorki, nawet jej artykułów, do których polemiki wklejała. Pisarka starała się więc uchronić od zapomnienia dzieje recepcji swojej twórczości, ale nie część swoich tekstów (zachowały się publikacje książkowe i część prasowych), rozrzuconych po różnych czasopismach, spoczywających teraz - jeśli w ogóle - w przepastnych bibliotecznych zbiorach.

Sam życiorys Kazimiery Alberti pełen jest niedopowiedzeń i niejasności, zwłaszcza jeśli chodzi o lata 1945-1962, kiedy to zupełnie zniknęła z polskiej sceny literackiej. Urodzona najprawdopodobniej pod koniec XIX wieku w Bolechowie ${ }^{2}$ pisarka swoje pierwsze literackie kroki, jak sama przyznaje w jednym z wywiadów (Alberti 1930), stawiała we Lwowie, gdzie też ukończyła gimnazjum, studia polonistyczne i konserwatorium oraz związała się Kołem Literacko-Artystycznym działającym

1 Zeszyty bibliotece IBL PAN (Warszawa) w 1977 roku przekazała przyjaciółka pisarki Maria Grabowiecka. Być może istniał lub istnieje zeszyt, w którym Alberti wklejała swoje artykuły, ale nie udało mi się dotrzeć do informacji na ten temat (zob. np. Magiera 2010: 131). Większość cytowanych przeze mnie wypowiedzi krytyków pochodzi z tych zbiorów.

2 Rosner podaje rok 1898, choć co do daty narodzin Alberti istnieją wątpliwości. Rodzicami pisarki byli Antoni Szymański i Maria z Filipowskich. Zob. Rosner 1982: 105.

72

Fabrica Litterarum Polono-Italica | 2019, nr 1 (1) 
przy tamtejszym kasynie (informacje podaję za: Rosner 1982: 105) ${ }^{3}$. Debiutowała w 1927 roku tomem Bunt lawin, przed drugą wojną światową wydała jeszcze kilka innych zbiorków wierszy, m.in.: Mój film (1927), bardzo dobrze przyjętą Pochwałę życia i śmierci (1930), Więcierz w głębinie (1937) oraz trzy powieści: Tatry, narty, miłość (1929), Ghetto potępione (1931) i Ci, którzy przyjdq (1934). Na początku lat trzydziestych ubiegłego wieku zamieszkała w Białej - wraz z mężem Stanisławem Albertim, znanym tłumaczem z języka czeskiego, który przyjął funkcję starosty bialskiego. Pisarka skutecznie rozbudziła życie kulturalne i artystyczne Białej oraz Bielska, była organizatorką wielu wystaw, spektakli oraz spotkań autorskich, prowadziła salon literacki, w którym gościli wybitni przedstawiciele miejscowej inteligencji, sama poetka była zapraszana na różne mniej i bardziej oficjalne spotkania artystów ${ }^{4}$, przyjaźniła się z Witkacym, który kilkakrotnie sportretował ją i jej męża (por. np. Wyleżyńska 1934). Była tłumaczką z języków: czeskiego i bułgarskiego, oraz propagatorką kultur słowiańskich, dużo podróżowała, dzieliła się też swoimi wrażeniami z wojaży w czasie wielu odczytów ${ }^{5}$, określała się jako pacyfistka, udzielała się społecznie i charytatywnie.

Wojenny i powojenny okres życia poetki, o czym już była mowa, nie jest dobrze znany. Z całą pewnością można stwierdzić jedynie, że część drugiej wojny światowej, od czasu zaciągnięcia się Stanisława Albertiego do wojska aż do wieści o jego śmierci, spędziła Alberti we Lwowie, potem wyjechała do Krakowa i działała tam w ruchu konspiracyjnym. W 1945 roku emigrowała do Włoch, gdzie wyszła powtórnie za mąż za adwokata Alfa Cocolę z Bari (za: Rosner 1982). Na emigracji nie zaprzestała działalności literackiej, wydała m.in. cztery powieści reporterskie w tłumaczeniu męża: L'anima della Calabria (Dusza Kalabrii, 1950), Segreti di Puglia (Sekrety Apulii, 1951), Magia ligure (Magia liguryjska, 1952) oraz Campania, Gran Teatro (Kampania, wielki teatr, 1953), dobrze przyjęte przez włoską krytykę. Zmarła prawdopodobnie w Bari w 1962 roku, nieobecna już zupełnie w polskim życiu kulturalnym.

Bogata twórczość literacka Kazimiery Alberti z pewnością popadłaby w całkowite zapomnienie, gdyby nie działalność kilku pasjonatów i badaczy literatury. Po drugiej wojnie światowej nazwisko pisarki pojawiało się jedynie okazjonalnie w notach encyklopedycznych i słownikowych oraz w opracowaniach dotyczących literatury dwudziestolecia międzywojennego, poezji tatrzańskiej lub w publikacjach

3 Część z tych informacji nie ma potwierdzenia w dokumentach, co w korespondencji e-mailowej zgłaszał mi dr Jacek Proszyk.

4 Bywała „na Harendzie” z m.in. Witkacym, zob. Rosner 1982: 106-107.

5 Była m.in. we Włoszech, Francji, w Czechosłowacji, krajach bałkańskich. Najwięcej uwagi poświęcała Słowacji, co spotkało się z przychylnymi reakcjami prasy czechosłowackiej. Zob. m.in.: Věda a umění. Kronika. „Československá Republika”, 4.04.1930; Glossy. „Mladé Slovensko” 1928, č. 10; Polský hlas o slovenskej litertúre. "Slovanský denník”, 2.09.1928 (podaję za dostępnymi w bibliotece IBL PAN zeszytami). 
związanych z literaturą Podbeskidzia (np.: Golec, Bojda 1995; Radwańska-Paryska, Paryski 1995). Nie poświęcano ani samej pisarce, ani jej tekstom zbyt wiele uwagi. Jednymi z pierwszych osób, które przypomniały o Alberti byli: Tadeusz Kłak (1962) i Edmund Rosner (1982). Jednakże ich artykuły nie wzbudziły większego zainteresowania pisarką. Dopiero w ciągu ostatnich kilkunastu lat bialska autorka powoli wychodzi z mroków niepamięci: swoją pracę doktorską i kilka artykułów poświęciła jej Halina Magiera; od dłuższego czasu niemal całą swoją uwagę i wysiłek badawczy skupiła na Alberti, zwłaszcza na włoskim okresie jej twórczości, profesor Janina Janas (Uniwersytet w Bari). Ale chyba najwięcej - przynajmniej na niwie regionalnej - zawdzięcza Alberti Jackowi Proszykowi, który nie ustawał i nie ustaje w trudach nie tylko popularyzacji jej twórczości i osoby ${ }^{6}$, ale także zbierania trudno dostępnych materiałów dotyczących pisarki.

Twórczość Kazimiery Alberti była dość zróżnicowana i nierówna, przeplatały się w niej, sąsiadowały ze sobą utwory kiepskie i te co najmniej dobre, aktualne także dzisiaj. Ale nie o całej twórczości pisarki będzie tutaj mowa. Skupię się zaledwie na wycinku, podskórnym nurcie, tle dwóch powieści: Ghetto potępione i Ci, którzy przyjdq, oraz na tomiku wierszy Więcierz w głębinie. Postaram się odtworzyć opowieść o ludziach odrzuconych, zapomnianych czy niechcianych w społecznej pamięci, w mieszczańskim polu widzenia, ale też dość tendencyjnie przedstawionych: za pomocą niezróżnicowanych określeń, stałych połączeń wyrazowych, stereotypów. Opowieść ukrytą nieraz za nie najciekawszą fabułą i papierowymi pierwszoplanowymi bohaterami, ale na tyle wyrazistą i pełnokrwistą, że zwracającą uwagę także przed laty (por. m.in. Czachowski 1931; Milikiewiczowa 1931; Negtsab 1934; [b.a.] 1934; wytykano jednak Alberti błędy merytoryczne, por. np. Hirszhorn 1931, M.K. 1931).

Pierwszy z przywołanych utworów to, jak mówi podtytuł, „powieść o duszy żydowskiej", jego główną bohaterką jest Róża Grünszpann, wyrwana ze swojego środowiska (biednej, żydowskiej dzielnicy w jednym z podkarpackich miasteczek) przez ciotkę Reginę, uciekinierkę z getta, obecnie światowej sławy śpiewaczkę. Otóż Róża wychowywana w środowisku areligijnym, światowym, w luksusie, wciąż czuje niedosyt, budzą się w niej dziwne myśli i pragnienia - „dusza żydowska”, która z ogromną siłą zacznie się rozwijać po wizycie w rodzinnym getcie i doprowadzi bohaterkę do porzucenia kariery malarskiej oraz artystycznego stylu życia na rzecz studiów medycznych, niesienia pomocy biednym i zabobonnym pobratymcom. Fabuła drugiej powieści jest równie schematyczna: Helena Rumiszewska, owoc związku „prawdziwego mieszczanina” Franciszka Rumiszewskiego z wywodzącą się z rodziny robotniczej Karoliną Kurkówną, wyraźnie odstaje od mieszczańskiej rodzi-

6 Wszystkie swoje działania opisuje na blogu: http://www.jacekproszyk.blog.bielsko.pl/ [dostęp: 20.08.2011] i https://proszyk.blogspot.com/2016/11/27-listopada.html [dostęp: 20.12.2018]. 
ny, burzy konwenanse, jako nauczycielka chce zmieniać młodzież, co nie spotyka się z uznaniem kołtuńskiego grona pedagogicznego i kończy się przeniesieniem dzielnej bohaterki na prowincję, gdzie Helena odnajduje się w nowej misji wyleczenia Bocza (także z mieszanego, ale tym razem katolicko-żydowskiego małżeństwa) z suchot i onanizmu.

Mamy tu do czynienia - podobnie jak w przypadku Róży - z dość szablonowym „pełnym człowiekiem”7, kobietą na wskroś współczesną i wyzwoloną. Ale w tych powieściach nie fabuła wydaje się najważniejsza, lecz napisane z publicystyczną pasją opisy odrzucenia nędzarzy, samotności „mieszańców”, „kundli ludzkich”. I choć Alberti nie starczyło talentu, a może tylko chęci dopracowania tekstów, by przekonująco przedstawić wszystkie postaci, umotywować ich działania, nie ulegać schematom i uproszczeniom, to należy - za krytykami międzywojnia - powiedzieć, że posiadała ona ogromną wrażliwość społeczną i talent do opisywania tzw. dołów społecznych. To właśnie postaci drugo-, trzecioplanowe, pejzaże, tła, miejsca ważne tylko w niektórych rozdziałach tych książek, stanowią o ich wartości. Dziś już nie rażą erotyczne sceny, przez które pisarka była oskarżana o pornografię ${ }^{8}$, ale opisy getta czy wiejskiej lub miejskiej biedy wydają się nadal żywe i poruszające, a obserwacje i refleksje na palące wówczas tematy przynajmniej częściowo aktualne.

Ci, którzy wchodzą do porządnych mieszczańskich domów drzwiami od kuchni, od podwórka, mieszkający w ciasnych, gnijących mieszkaniach, nieogrzewanych ruderach. $\mathrm{Ci}$, którzy wierzą w nieprawdopodobne wręcz zabobony, którzy są mięsem armatnim w cudzych wojnach. Obcy: innej wiary, nieznani, odepchnięci, niechciani, niebezpieczni, obecni w publicznym dyskursie tylko przy okazji akcji charytatywnych, jako przestroga lub na prawach „egzotycznego” zjawiska. Tacy, których się nie dotyka i do których się nie mówi. Sami pozbawiani głosu. Słudzy, pomywacze, chłopi, robotnicy, Żydzi z getta, wychrzty: nędzarze.

Opisywaną przez Kazimierę Alberti nędzę można rozumieć dwojako: po pierwsze w dosłownym, ekonomicznym znaczeniu, po drugie: jako formę odrzucenia przez społeczeństwo. Najtragiczniejsze w skutkach jest odrzucenie uświadomione, rejestrowane ze wszystkimi szczegółami, a więc tym boleśniejsze; prowadzi ono do zaprzeczenia własnej tożsamości, rozdwojenia, znienawidzenia siebie, do prób zmiany stanu rzeczy, ucieczki. Ale nędzy - obojętnie: żydowskiej, robotniczej czy

7 Pojęcie zastosowane przez Alberti określa tym mianem Różę po metamorfozie, w pełni oddaną sprawie pomocy biednym i potrzebującym - zob. Alberti 1931: 320. Wszystkie cytaty przytaczam w oryginalnej pisowni.

8 Skonfiskowano pierwszy nakład utworu Ci, którzy przyjdq, o czym rozpisywały się ówczesne gazety. 
chłopskiej - nie można się pozbyć przez samo wyrwanie się z getta, suteren czy wsi. Tkwi ona w bohaterach Alberti, wpływa na całe ich życie, bywa motorem przemiany, ale też - często nawet nieświadomej - klęski. Sprawia, że wszyscy nędzarze są „wielką rodziną”, są do siebie podobni, te same rzeczy w nich tkwią i kłują, żądlą nawet po wielu latach. Pisze Alberti, że „każda nędza jest podobna do siebie”:

Jest jednakowa. Żydowska czy też chłopska. [Zrozumiała, ż]e tu niema ani rozdziału, ani stopni, według których należy tę traktować tak, a tę inaczej. Nad jedną przechodzić do porządku dziennego, nad drugą się wzruszać (Alberti 1931: 281).

To Judymowy dług, który trzeba w jakiś sposób spłacić, nawet własnym kosztem: podążając czasem ścieżką bohatera Żeromskiego, podejmując próby zmienienia świata, stale kończące się mniejszymi i większymi niepowodzeniami czy - przez powszechny ostracyzm, przez wytykanie minionej lub obecnej nędzy - popełniając samobójstwo.

Piekło odrzucenia jest chłonne i pojemne, składa się z czterech rozległych kręgów, u podstaw których tkwi bieda. Im głębiej, tym większa świadomość swojej nędzy, tym częstsze próby buntu i - choć nie w każdym wypadku - boleśniejsze upadki. W pierwszym kręgu znajdują się Żydzi z podkarpackiego miasteczka opisani w Ghetcie potępionym (Alberti 1931), żyjący w bardzo złych warunkach, ciężko doświadczani przez los, ale godzący się z nim, pokorni. Trwający niezmienne od wieków, mimo biedy, głodu i chorób, to ich nazywa bialska pisarka „arystokratami nędzy".

Drugi zaludniają chłopi, główni bohaterowie kalendarzowego cyklu Więcierz $w$ głębinie z tomu pod tym samym tytułem (Alberti 1937), epizodycznie pojawiający się także w utworze Ci, którzy przyjdq (Alberti 1934a); godzą się oni ze swoją nędzą, ufnie oddają się w ręce Boga, ale zaczynają - choć nieśmiało - wątpić w Jego sprawiedliwość i dobroć, a wątpiąc, zyskują cząstkową przynajmniej świadomość własnej sytuacji.

Trzeci krąg zamieszkany jest przez szeroko pojętą biedotę miejską, drugoplanową, ale wielką bohaterkę utworu Ci, którzy przyjdq oraz Czerwonej wiosny (część tomu Więcierz w głębinie), to głównie różnego typu robotnicy, których największym przekleństwem - oprócz nędzy - jest samowiedza. To właśnie refleksja nad swoją sytuacją ekonomiczną i społeczną daje siły do sprzeciwu, buntu, choć też, paradoksalnie, podcina skrzydła.

W ostatnim, najgłębszym kręgu znajdują się ci, którzy zostali odrzuceni nie (lub nie tylko) ze względu na swoją biedę, nieestetyczność czy niezrozumiałą kulturę, jak wymienieni wyżej, ale z powodu samego faktu bycia sobą. To mieszańcy, ludzie żyjący jednocześnie $w$ dwóch światach, ale nieczujący pełnej przynależności do 
żadnego z nich, mający podwójną tożsamość budzącą wewnętrzne konflikty; takich postaci tylko w dwóch powieściach Kazimiery Alberti jest wiele, to Róża Grünszpann i Marek Gnieciuch z Ghetta potępionego, Karolcia Kurkówna, Franciszek Rumiszewski, Helena Rumiszewska i Boczo z Ci, którzy przyjdq.

Mieszkańcy pierwszych trzech kręgów odrzucenia są do siebie podobni, ich nędza jest jednakowa, żyją w zbliżonych, bardzo trudnych warunkach; różnią się jedynie poziomem akceptacji swojej sytuacji. Zwątpienie, wreszcie niezadowolenie i bunt narastają stopniowo. Pierwszy krąg jest raczej przedsionkiem piekła niż piekłem samym, bo choć nędza panuje tu dotkliwa, nie przeszkadza ona - jak się wydaje - większości mieszkańców getta. Żyją i umierają w biedzie, tak samo jak ich pradziadowie, dziadowie, rodzice i dzieci. Nie znają innego świata, nie wyobrażają sobie - z małymi wyjątkami - życia poza gettem. Owszem, są odrzuceni przez społeczeństwo, nikt się nimi nie interesuje, ale też sami tego zainteresowania nie szukają. Nawet u bogatych współwyznawców ${ }^{9}$. Chłopi - pełni pokory w większości wierszy kalendarzowego cyklu, zaczynają wątpić w boską sprawiedliwość, ocierając się niemal o bluźnierstwo. Biedota miejska coraz dotkliwiej odczuwa poniżenie i niedostatek. Nawet jeśli nie wszyscy jej przedstawiciele decydują się wyraźnie popierać ruchy o zabarwieniu rewolucyjnym, to większość zaczyna odważnie wyrażać swoje niezadowolenie, nie szukając już pocieszenia w modlitwie.

Alberti łączy mozolne budowanie własnej wartości, zyskiwanie samoświadomości, wreszcie chęć emancypacji, zdobycia praw z odrzuceniem religii jako jednego z czynników zniewalających człowieka - również człowieka „na stanowisku”; ciemnota i zacofanie mieszczaństwa także pokazana jest przez ich nadmierne, absurdalne $^{10}$ wręcz, przywiązanie do katolicyzmu11. Brakuje w tych tekstach pogłębionej analizy stosunku człowieka do Boga. Alberti, jeśli już zastanawia się nad religią, rozpatruje jej społeczne funkcje. Wyrzeczenie się religii, co uczyniła Róża, lub niewykazywanie zainteresowania nią w przypadku Heleny, było - jak się wydaje - niezbędne, by metamorfoza w „człowieka pełnego” mogła się dokonać.

9 Szlojma, ojciec Róży, nigdy nie poprosił swojej siostry - sławnej śpiewaczki - o pomoc.

10 „Gdy kogoś zabolały zęby, odmawiało się naprzód modlitwę do św. Apolonii, a potem dopiero szło się do dentysty. Gdy coś zaginęło, odprawiało się nowennę do św. Antoniego przez siedem dni, a dopiero potem dawało się znać policji" (Alberti 1934a).

11 Chodzi tu raczej o zewnętrzne oznaki „folkloru religijnego" niż o wyznanie. 
Getto z powieści Alberti to miejsce ciemne, opanowane przez przesądy i chciałoby się powiedzieć - zło zaniechania, marazm, rezygnację. Nie ma w nim żadnego jasnego punktu, żadnej nadziei na zmianę, a nawet chęci zmiany. Jego uliczki są wąskie, kręte, błotniste, pełne zaułków; domki - niskie, ciasne, zniszczone, krzywe, z dziurawymi rynnami i dachami, walącymi się kominami, z sadzą i brudem na szybach, śmieciami na progach; niewiele lepsze od nich są podwórka:

Zaplute podwórka, pełne dziwacznych zakamarków, przybudówek, rozchwianych ganków, komórek [...]. Podwórza zasłane skorupami jaj, na których bawi się rozkrzyczana, obdarta dzieciarnia. Na [...] sznurach wietrzą się przepocone, wytłamszone bety, ohydne, zatłuszczone pierzyny, poduszki ze śladami rozgniecionych pluskiew, much i pająków [...], zjedzone przez mole chałaty i brudne z czarnemi pasami tałesy (Alberti 1931: 11).

Getto zamieszkane jest przez ledwo wiążącą koniec z końcem przesądną biedotę o „czarnych duszach”, pełno tu zaniedbanych kobiet z osuwającymi się, przetłuszczonymi perukami, dziewcząt, które starzeją się w zastraszającym tempie i w wieku trzydziestu lat wyglądają jak babcie, mężczyzn mizernych, chwytających się jakichkolwiek prac, bardzo religijnych, czasem rzucających wszystko dla studiowania świętych ksiąg, dzieci cały czas umierających i rodzących się - tak, że można stracić rachubę, gruźlików dających swoim dzieciom w ostatnim akcie rodzicielskiej miłości zatrute zarazkami mleko, niewykwalifikowanych akuszerek usiłujących wyleczyć chore niemowlęta odczynianiem uroków... Całości dopełniają mizerne drzewa i wychudzone zwierzęta. Wszystko tutaj żyje i cierpi jednako. Getto w czasie wielkiej wojny było jeszcze biedniejsze, jeszcze bardziej pokrzywdzone przez los, żydowskie kobiety - bez względu na wiek i aparycję - były gwałcone i bite, dzieciom zabierano i tak gnijące już resztki jedzenia, zaś zarówno chorych, jak i zdrowych mężczyzn powoływano do wojska. Ale i do tego można było się przyzwyczaić, „jakoś to życie płynęło" (Alberti 1931: 2-64), cała nędza czasu wojny i pokoju znoszona była z niezmienną, „wrodzoną temu ludowi” pokorą (Alberti 1931: 69-71).

Opis getta nie byłby pełny, gdyby nie jego mieszkańcy - tacy na przykład Grünszpannowie, rodzina, jakich wiele. Historia, jakich wiele. Żydowskim everymenem w powieści Alberti jest Szlojma Grünszpann, syn grabarza i szwaczki (szyjącej pośmiertne koszule), niemal cały swój czas poświęcający studiowaniu najważniejszych ksiąg judaizmu. Chory od wielu lat na gruźlicę, która - gdy podejmował pracę - niweczyła jego plany, odbierając siły. Mieszkał w jednej izbie z żoną Klarą i kilkorgiem dzieci, z których jedno, o czym już wyżej była mowa, wzięła jego siostra na wychowanie.

Szlojma nigdy nie narzekał, mimo nędzy uważał się za szczęśliwego człowieka. Wierzył - bez względu na warunki, w jakich przyszło mu żyć, czy na doświadczane 
zło - niezmiennie i bez żadnych wątpliwości w Boga. Wciąż cytował fragmenty z ksiąg, w nich szukał oparcia w trudnych chwilach, ale nie zadawał pytań, rzadko kiedy o coś prosił. Cały czas dziękował Bogu za dobroć12, cytował Torę, Misznę, Gemarę, modlił się, ale nigdy nie próbował rozmawiać z Bogiem¹3. Nędzę, bicie w wojsku, śmierć dzieci, swoją chorobę, a wreszcie powolne i bolesne umieranie przyjmował jako coś oczywistego, czego nie da się uniknąć. Do śmierci był zresztą przyzwyczajony od wczesnego dzieciństwa - nie tylko dzięki profesji rodziców; on sam, tak jak jego przodkowie, kierował się żydowskim przysłowiem „szklanek i dzieci nigdy nie za dużo" (Alberti 1931: 23), dzieci rodziły się i umierały tak szybko, że przyzwyczajano się do ciągłych pogrzebów. Szlojma pragnął, by jego potomstwo żyło tak samo jak on. Dlatego też nie chciał początkowo oddać siostrze córki, dlatego wysłał swoich synów na nauki do chederu. Pragnął mieć swoje dzieci przy sobie, w getcie, wprowadzał je w tradycyjny świat, odcinając tym samym od wszystkiego, co na zewnątrz. Takiego postępowania nie mogła zrozumieć postępowa, wykształcona Róża, gdy po kilkunastu latach nieobecności odwiedziła rodzinne getto:

Znów zacznie [młodszy brat Róży - K.P.] się kiwać nad tym Talmudem jak ojciec, jak Szmajuś. Znów wyrośnie z niego pokorny, głupi, skostniały w przesądach nędzarz żydowski. Czarny, chory, próżniaczy chałaciarz, - myślała Róża, pieniąc się wewnętrznie. Nie nauczą go ani czytać, ani pisać w języku tego kraju, w którym mieszka. Będzie odseparowany od wszystkich. Sam się od całego społeczeństwa oddali. Będzie siebie uważał za kogoś mądrzejszego, wyższego od „gojów”. Za latorośl z „rodu wybranych”. I będzie uparcie powtarzał: „Izrael am kdoszym hemo”. Zamknie się w swem ghetcie. Nie wystawi nosa na powietrze. W brudzie będzie żył i zdychał. W zaszmelcowanych betach skona. I najgroźniejsza rzecz, że będzie mu z tem wszystkiem dobrze. Że nie pomyśli, aby mogło być inaczej. Że nie zapragnie nigdy, ani na chwilę innego życia, czystej koszuli i kalesonów, szczotki i mydła, ciepłej wody i chustki do

12 W czasie wojny (Alberti 1931: 61, 71), a nawet przed własną, bardzo bolesną śmiercią (Alberti 1931: 174-178).

13 Szlojma używa Jego słów, rozumie - jak pisze sama Alberti - zamiary Boga, tajemnicę i sens przeznaczonej mu drogi (zob. m.in. Alberti 1931: 178-179). Wydaje się jednak, że nie jest nastawiony na słowo Boga, że nie rozmawia z nim, wykonuje tylko skrupulatnie wszelkie nakazy umieszczone w księgach, przestrzega zakazów; pocieszenia szuka w Piśmie, ale nie w rozmowie. Inaczej w obliczu wielkiego kataklizmu - pierwszej wojny światowej - zachowywali się Żydzi opisani przez Stryjkowskiego, w nich budziło się zwątpienie, próbowali rozmawiać, a nawet targować się z Bogiem (por. Stryjkowski 1979: 79, 88, 150). W powieści Alberti to narratorka próbuje zadawać pytania, wplątuje się w gęste rozważania nad teodyceą, ale także brakuje jej nastawienia na dialog, skupia się na oskarżaniu, jej wypowiedzi są szeregiem pytań retorycznych - tyle robiącym wrażenie, co nic niewnoszącym. 
nosa. I choćby mu ktoś kładł łopatą do głowy, że tak byłoby lepiej, zdrowiej i czyściej - nic - uśmiechnie się filozoficznie (Alberti 1931: 212-213).

Nędza wiejska zbliżona jest do żydowskiej: i tutaj pojawia się głód, umierające z zimna i chorób dzieci, brak najpotrzebniejszych rzeczy, tutaj także jedynym wyjściem, ale niewielu przychodzącym do głowy, wydaje się ucieczka ${ }^{14}$. Niedolę dopełniają ciągłe zmagania z naturą: powodziami, głodnymi zwierzętami, suszami, pożarami. Nie jest jednak ona tak dokładnie i tak obrazowo przedstawiona jak nędza żydowska. Najwyraźniej los polskiego chłopa został przez Alberti opisany w kalendarzowym cyklu wierszy-modlitw Więcierz w głębinie (Alberti 1937: 46-78), w którym dominują modlitwy błagalne; a wraz z mijającymi miesiącami nędza wydaje się coraz bardziej dotkliwa i przerażająca. Poetka w każdym kolejnym wersie dodaje nowe szczegóły; i chociaż w części tekstów przeważa tryb przypuszczający, z łatwością można się domyślić, że opisywane wydarzenia są już czymś dobrze znanym chłopom: pękający pod dorożkami lód, pochłaniająca je woda, głodujące dzieci, kaszlący starcy, noworodki niedożywające wiosny, płonące stodoły, żebracy, których nie ma czym poczęstować, zamarzające ściany...

Chociaż chłopi akceptują naturalny cykl życia i śmierci (Maj), godzą się ze swoim ubóstwem, zdają na łaskę Pana, to stopniowo poczucie krzywdy bierze górę, a prośby do Boga stają się coraz śmielsze, coraz wyraźniej ukazują niedolę. Kataklizm wojny („sczerniałe w dymie bitew twarze”, „krwią gęstą zalane bandaże”, „kula, trucizna i miecz”; Maj), brak ratunku, gradobicia zabierające i tak zbyt małe plony (Czerwiec), a w końcu głód, choroby, powodzie zaczynają być postrzegane jako kara zesłania przez gniewnego Boga. Staje się On nawet synonimem śmierci: „i podpełzniesz zdradliwie do kaszlących warg, / jakiś tragiczny, straszny przeprowadzasz targ, / oczywiście zwyciężysz. Nic już nie zazgrzyta” (Listopad). Reakcją na to okrucieństwo stają się wyraźne już prośby, próby „zastraszenia”, „zmuszenia” Pana do łagodności, najpierw jeszcze nieśmiałe - Jego oczy mają przestraszyć się chłopskiej nędzy (Czerwiec), jednak wraz z upływem czasu i narastania krzywdy owe próby stają się odważniejsze - krzyk nędzarzy ma przerazić Boga tak, że nigdy go nie zapomni (Listopad), bowiem będzie to krzyk rozpaczy, która - w ostateczności prowadzi do zwątpienia:

14 Jedynym opisanym w tekstach Alberti przypadkiem ucieczki ze wsi był profesor Tomasz Gnieciuch, drugoplanowy bohater z powieści Ci, którzy przyjdq.

15 Tytuły cytowanych i przywoływanych wierszy podaję w nawiasach, wszystkie utwory znajdują się w przywołanym zakresie.

80

Fabrica Litterarum Polono-Italica | 2019, nr 1 (1) 
I gdzie są te życzliwe z dalekich stron króle, gdzie ich złoto, kadziła i szkatułka z mirrą i gdzie zwierzęta, które chuchać mają czule, gdzież dziady uśmiechnięte z staromodną lirą? [...]

O Panie! gdzie jest gwiazda? gdzie gwiazda?

(Grudzień)

Tak zwana „biedota miejska” (zaliczano do niej też ludzi pracujących, robotników, wykonujących „zawody niegodne” biedniejszych mieszczan) żyła w o wiele lepszych warunkach niż Żydzi w getcie czy chłopi. Owszem, mieszkania miała równie małe, ale za to dość dobrze zaopatrzone, jadła żywność pośledniejszego gatunku, zwłaszcza w czasie wojny, ale nie głodowała tak bardzo jak wyżej opisani. Domy „Kądziołków i Kurków” były takie, w jakich mieszkały tysiące robotników w wielu miastach, wchodziło się do nich od podwórka, po kilku lub kilkunastu stromych schodach; były malutkie, jedno-, dwuizbowe, ale czyste i w miarę możliwości zadbane. Ich mieszkańcy mieli tylko po dwa ubrania: codzienne i to „na niedzielę, na wiece i na demonstracje” lub na pogrzeb, także własny (Alberti 1934a: 37).

Powodziło się im lepiej niż wielu biedniejszym, ale znaleźli się - przynajmniej w świecie powieściowym Alberti - głębiej, dalej w piekle odrzucenia. Listonosze, robotnicy, praczki codziennie spotykali się z lekko tylko ukrywanymi niechęcią i pogardą. Cały czas musieli konfrontować własną biedę z bogactwem innych, cały czas znosili upokorzenia. To nie ich wpuszczano frontowymi drzwiami, które były zarezerwowane dla ludzi o określonym statusie, mających pieniądze, wpływy, cieszących się społecznym szacunkiem (Alberti 1934a: 71). Tymi drzwiami wchodzili Rumiszewscy ${ }^{16}$ - i im podobni, a więc mieszczańscy hipokryci, zatwardziali w swoich przekonaniach, przyzwyczajeniach i ciemnocie, tkwiący w przesądach i egoizmie. Dla biednych przeznaczone były schody kuchenne, od podwórka:

Tędy wchodził inny świat: świat brzydki, nędzny, plujący i przeklinający na schodach (czasami na tych schodach płaczący), świat obdarty, bez bucików, bez chleba, często bez dachu nad głową. Świat zapocony, pracujący, o czarnych żylastych rękach i kaszlących piersiach. Świat Kurków. Wchodzili przez schody kuchenne (Alberti 1934a: 72).

16 „Odpowiednik” Dulskich. Trzeba zresztą przyznać, że Alberti świetnie opisała mieszczańskie rodziny. Niektórzy krytycy porównywali przebłyski talentu bialskiej pisarki widoczne w scenach u Rumiszewskich z pisarstwem Zapolskiej (Negtsab 1934; por. Podhorska-Okołów 1931).

81

Fabrica Litterarum Polono-Italica | 2019, nr 1 (1) 
Dla tego świata zarezerwowana była forma „wy” (nigdy nie zwracano się do biednych czy służących per „Pan”, „Pani” - zob. np. Alberti 1934a: 72), a każda ich wizyta - czy to praczki, elektryka czy kogokolwiek innego - budziła niezadowolenie cioci Klimusi Rumiszewskiej, była dla niej przykrą koniecznością. Podobnie jak dla „innych Rumiszewskich" przykre było to, że córka praczki, Karolcia Kurkówna, udziela ich dzieciom korepetycji. Aby jednak nie zapomniała, skąd pochodzi i gdzie jest jej miejsce, często mówiono jej, żeby przypomniała mamie o bieliźnie do odebrania czy o praniu do zrobienia. „A mówiło się tak oczywiście w obecności Lili, albo Danuty, albo innej Krzysi, aby wiedziały, że one co innego - a Karolcia, córka »tej Kurkowej« chociaż zdolna - to także co innego" (Alberti 1934a: 41). Nie pozwalano Helence, wychowywanej na przykładną przedstawicielkę swojej klasy, widywać się z Andzią Kądziołkówną, ponieważ - jako dziecko listonosza - była „nieodpowiednim towarzystwem" dla młodej panny z dobrego domu (Alberti 1934a: 65).

Tak długo i intensywnie wpajano „tym wchodzącym od kuchni”, że są gorsi, że istnieje ogromna przepaść, nie tylko finansowa, pomiędzy nimi a bogatymi mieszczanami, że częściowo sami w to uwierzyli, czuli się nieswojo, gdy przyszło im rozmawiać z „panami”, uważali się za mniej wartościowych, jak na przykład pani Józefa Kądziołkowa, matka Andzi. Kiedy jej córkę odwiedzała Helena Rumiszewska, żona listonosza zawsze przed przywitaniem wycierała dłonie, „choćby nie wiedzieć jakie miała czyste ręce”. "Był to dziwny ruch. Ruch ludzi, którym się zawsze w obliczu "państwa « wydaje, że mają niezbyt czyste ręce i muszą je koniecznie obetrzeć" (Alberti 1934a: 94).

Jednak nie wszyscy się godzili z takim stanem rzeczy. Wśród robotników, podobnie jak wśród chłopów, zaczynało wzrastać poczucie krzywdy i niesprawiedliwości, ale jednocześnie zyskiwali też świadomość własnej wartości i siły. Nędza i odrzucenie stały się podstawami ich buntu. Buntu, który w Ci, którzy przyjdq jest tylko lekko zarysowany: praczka Bazylowa na stwierdzenie cioci Klimusi, że widocznie Bazyli musiał zginąć na wojnie, bo taka jest wola Boża, odpowiada z żalem i złością: „Zginął, bo mu tak psie krwie - kazali! On tam sam ginąć nie chciał” (Alberti 1934a: 80-81), ojciec Karolci interesuje się polityką, czyta lewicowe gazety, chodzi na manifestacje... Jednak bunt ten w pełni - chociaż bardzo naiwnie - pokazany jest w kilku wierszach z Czerwonej wiosny (Alberti 1937: 21-41)17. Wystarczy powiedzieć, że protest tych - już świadomych siebie oraz swoich społecznych praw i obowiązków - robotników nie będzie miał nic wspólnego z brutalnymi działaniami, daleko mu będzie do agresywnych wystąpień, z pewnością już wtedy znanych autorce wierszy. Ich rewolucja będzie „rewolucją o szczęście człowieka” (Wiec robotników), a więc bez przelewu krwi, bez broni. Wezmą w niej udział „sękaci, zgłodniali i bez

17 Tytuły cytowanych i przywoływanych wierszy podaję w nawiasach, wszystkie utwory znajdują się w przywołanym zakresie.

82

Fabrica Litterarum Polono-Italica | 2019, nr 1 (1) 
kołnierzyków, / pełni plam wątrobianych, żylaków i sińców" (Wiec robotników), ci tak często traktowani z pogardą pracownicy rafinerii, tartaków i garbarni, wyprostują zgięte pracą plecy i podniosą pięści (Czerwona wiosna). Co dokładnie mają wywalczyć? Autorka nie odpowiada na to pytanie, ani nawet nie snuje domysłów...

Kazimiera Alberti starała się dość dokładnie opisać środowiska, z których wywodzili się jej bohaterowie, a umieszczając ich w światach skrajnie odmiennych, wyostrzała jeszcze ich nędzę. W powieściach, będących głównym przedmiotem mojego zainteresowania, wiele jest postaci żyjących w dwóch rzeczywistościach: tej pierwszej, znajdującej się wciąż na dnie duszy, nędznej i przerażającej, czarnej, brudnej oraz drugiej: pełnej dobrobytu, nawet przepychu, kolorów, podziwu i szacunku. Postaci zawieszone między dwoma rzeczywistościami są do siebie dosyć podobne, idą niemal tą samą drogą, z jedną tylko różnicą: niektóre są za słabe, by kroczyć nią do końca. Spadają wtedy na dno swego kręgu piekła.

Bohaterki kobiece cechuje nadzwyczajna uroda - Róża Grünszpann i Karolcia Kurkówna są olśniewająco piękne, Helena Rumiszewska także jest urodziwą kobietą o posągowych kształtach. Uroda wyróżnia je już spośród czarnych, szarych lub żółtych robotniczych czy żydowskich twarzy ${ }^{18}$. Są inne od początku, jakby przeznaczone do czegoś więcej niż kontynuowania losu swoich rodziców. Róża, jak już wspomniałam, została wyrwana z getta przez przypadek, awansu społecznego nie zawdzięczała sobie. Podobnie Helena - urodziła się i wychowała w rodzinie mieszczańskiej, matki - córki robotników - prawie nie pamiętała. Jedynie Karolcia Kurkówna uparcie dążyła do celu, choć nie chodziło jej o porzucenie swojego środowiska, którego nigdy się nie wypierała i nie wstydziła, a raczej o własny rozwój. Przez jakiś czas dorabiała jako nauczycielka i przygotowywała się do egzaminów na studia medyczne, zbierała każdy grosz, by mogła wyjechać studiować do Szwajcarii, gdy w końcu jej się to udało, budziła powszechne zdziwienie wśród „państwa”, ale też podziw i dumę rodziców. Nie prosiła o wejście do wyższej klasy, wśród Rumiszewskich znalazła się tylko dlatego, że jej narzeczony i późniejszy mąż, Franciszek, nie mógł wyrwać z siebie „ciasnego, ciemnego mieszczaństwa” (Alberti 1934a: 23), chciał wrócić do bliskich.

Dopóki Karolcia nie poznała rodziny męża, nie czuła się odrzucona; owszem, zdawała sobie sprawę, że istnieją ludzie, których nie interesuje „Nic więcej, tylko to, że mają pieniądze" (Alberti 1934a: 47), wyczuwała być może protekcjonalny ton matek i ojców swoich uczniów, ale nie czuła się niechciana, „poza miejscem”, „nie u siebie”. Dopiero Rumiszewscy pokazali jej, czym jest odtrącenie i brak ak-

18 O bardzo charakterystycznych przedstawieniach ubogich ludzi piszę w dalszej części artykułu.

83

Fabrica Litterarum Polono-Italica | 2019, nr 1 (1) 
ceptacji; udowadniali jej przy każdej sposobności, że jako córka robotników, ze złym imieniem i jeszcze gorszym nazwiskiem ${ }^{19}$, a do tego z dzieckiem urodzonym przed ślubem, nie ma czego szukać w porządnej, mieszczańskiej rodzinie. Była kolejną w historii polskiej literatury trędowatą: „Pardon! Ale wśród nas ona jest niewłaściwym elementem, elle n'est pas pour nous! Nie trzeba się z nią zbliżać i poufalić. [...] Jest dla nas - trędowata" (Mniszkówna 1972: 343-344). To zdanie mógł wypowiedzieć ktokolwiek z rodziny Rumiszewskich i idealnie pasowałoby do opisywanej przez Alberti sytuacji. Odrzucenie było tym dotkliwsze, że żadne oskarżenia nie padały wprost, były jednak „dostarczane” Karolci przez osoby trzecie. Duszna atmosfera mieszczańskiego domu²0, wyraźna niechęć rodziny męża były przyczyną jej samobójstwa. Trzeba przyznać - samobójstwa dość słabo umotywowanego psychologicznie. Alberti opisała historię Karoliny bardzo skrótowo, miała być ona tylko tłem dla dziejów Heleny, Kurkówna nie została więc potraktowana jak pełnoprawna bohaterka.

Co innego Helena - czytelnik może prześledzić całe niemal jej losy, widzi, jak kształtuje się świadoma siebie kobieta, ale też jak trudno jest jej zmagać się ze środowiskiem, w którym wzrasta i w którym później pracuje. Dzieciństwo naznaczone nakazami i zakazami cioci Klimusi, tajemnicą związaną ze śmiercią matki, w końcu odkryciem rodzinnego sekretu. Duży wpływ na młodą Rumiszewską miała też ucieczka z domu jej starszego brata, który zdecydował się na ten desperacki krok po kłótni z ciotką o Karolinę i przyczyny jej śmierci. Te dwa ostatnie wydarzenia zaważyły na dalszym życiu Heleny, wtedy to postanowiła sprzeciwiać się ciotce i innym Rumiszewskim; wybrała siebie, indywidualność - na tyle, na ile będąc niepełnoletnią, mogła: spotykała się więc z koleżanką, córką listonosza, jej umierającemu bratu przyniosła kwiaty do szpitala, nie wstydziła się tej znajomości i nie przejmowała tym, co ludzie powiedzą. Po skończeniu studiów zaczęła pracować jako nauczycielka. Uważała się za kobietę zupełnie już wyemancypowaną, nie tylko nie poddawała się obowiązującym, niesprawiedliwym zasadom, ale też starała się wychować młodzież - „tych, którzy przyjdą” - w duchu pacyfizmu. Jednak stosowane przez nią metody zostały uznane za nieodpowiednie i deprawujące. Znowu musiała zmagać się z zaściankowością i małostkowością, tym razem wśród grona pedagogicznego. W końcu została wydalona na prowincję, gdzie także chciała choć swoimi sposobami - wychowywać młodzież i uratować przed zatratą młodego chłopaka, pół-Żyda. Z prowincjonalnej szkoły także została wydalona, po tej ostatniej porażce zdecydowała się na wyjazd do Włoch.

19 „Matka Heleny nazywała się wcale nie pięknie. Karolina. A z domu Kurkówna. Czyż można to imię porównać z imionami w rodzinie ojca, gdzie kobietom dawało się na chrzcie świętym Marja, Ludwika albo Zofja, Wiktoria [...]" (Alberti 1934a: 35-36).

20 Często u Alberti duchota, brak świeżego powietrza, nieotwieranie okien są synonimami ciemnoty i zabobonu. Duszno było zarówno w mieszkaniu Grünszpannów, jak i Rumiszewskich.

84

Fabrica Litterarum Polono-Italica | 2019, nr 1 (1) 
Helena nie przeżywała odrzucenia tak bardzo jak jej matka, mimo że czuła je niemal z każdej strony; został z nią tylko ojciec i - choć ten wątek nie do końca jest jasny - jej ukochany Marek ${ }^{21}$. Już od najmłodszych lat odstawała od rodziny, co przez lata doprowadziło do powstania bariery nie do pokonania. Ciotki i wujenki, nie potrafiąc i nie chcąc zrozumieć wątpliwości czy przemyśleń młodziutkiej Heleny, jej potrzeby kontaktu z rówieśnikami niekoniecznie z dobrych, mieszczańskich domów, reagowały agresją i niechęcią na wszystkie inicjatywy dziewczynki; często nazywały ją „małą żmijką” (Alberti 1934a: 61-66).

Biorący swój początek w dzieciństwie, a może nawet $w$ historii matki, łańcuch niechęci, odrzucenia i poczucia obcości, ciągnął się przez całą historię Heleny. Jej dwa spotkania z gronem nauczycielskim były zetknięciem się z różnymi rodzajami dulszczyzny, z rodzicami zresztą też nie było lepiej - nie odpowiadał im sposób prowadzenia lekcji (dialog) i „propagowanie pacyfizmu”, część uczniów już upodabniała się do rodziców, poddawała się mieszczańskim prawom, stereotypom i przekonaniom (Alberti 1934a: 162-164). W miasteczku, do którego się przeniosła, było podobnie. Jej kolejny wyjazd, do Włoch, nie był jednak ucieczką ze strachu czy zniechęcenia; po odebraniu jej prawa do służby publicznej nie miała już czego szukać w kraju, postanowiła więc znaleźć sobie nowe miejsce do życia.

Helena była postacią jednowymiarową, nie przeżywała wewnętrznych rozterek. Tylko z niektórych, nielicznych zresztą zdań, można wywnioskować, że wydarzenia kończące książkę, a więc coś, co można by nazwać „odrzuceniem ostatecznym” (ujawnienie romansu z Boczem, wspomnianym pół-Żydem, dymisja, odrzucenie przez Bocza, który zakochał się w młodziutkiej Adzi, wyjazd do Włoch, niepewność związku z Markiem) były bolesne. Te odczucia zostają jednak po chwili złagodzone, pomniejszone, bo przecież Helena - co kilkakrotnie podkreśla się w powieści - jest silną kobietą:

Pewnie, że jeszcze to zakończenie rozdziału, który nazywa się „Boczo” będzie bolało, ale i to w końcu przejdzie. [...] W mgle widziała już swój nowy dom. Jeszcze niewyraźnie, ale już prawie czuła klucze w ręku. [...] jej własny i wszystko jedno czy zamieszka w nim sama, czy też z Markiem, gdy on zechce [...] (Alberti 1934a: 459-461).

Bardziej złożoną bohaterką, także „mieszańcem”, ale nie w dosłownym znaczeniu, była Róża Grünszpann. Jej niezbyt zawiła historia została już wyżej przytoczona, nie będę jej więc powtarzać. Najważniejsza w powieści wydaje się przemiana Róży w człowieka świadomego swoich społecznych obowiązków, „długu do spłacenia”. Główna bohaterka Ghetta potępionego nie pamiętała dobrze swojego dzieciństwa,

21 Którego, by być w zgodzie z własnym sumieniem, nakazującym pomoc potrzebującemu nawet za cenę związku, odrzuciła, zdradzając go z Boczem.

85

Fabrica Litterarum Polono-Italica | 2019, nr 1 (1) 
nie czuła się związana z żadną religią, z żadnym miejscem na ziemi. Do czasu, aż odwiedziła swoje rodzinne strony. Wtedy to wyklarowało się coś, co tkwiło w niej od dawna, a co przejawiało się w dziwnej przekorze, ciągłej chęci bycia gdzieś indziej, pozostawania w jakimś nieokreślonym pędzie. Rodziła się w niej „dusza żydowska". Początkowo przejawiała się jako nienawiść, obrzydzenie do tego, co widziała w getcie - wypowiedzi pełne tych uczuć przeważają w powieści Alberti - ale z czasem pojawia się coraz więcej litości, żmudne i często zakończone fiaskiem próby zrozumienia. Powolny rozwój tej specyficznej formy duszy skierował Różę na nowe tory: studia medyczne, niesienie pomocy potrzebującym; aby móc tego dokonać, musiała jednak podjąć wiele trudnych decyzji: sprzedawała resztki majątku ciotki, zrezygnowała z wygód, wyrzekła się miłości kochanego przez nią arystokraty; wszystko po to, by pomóc biednym, zabobonnym mieszkańcom żydowskiej dzielnicy.

Róża żyła w dwóch światach, ale w żadnym z nich nie czuła się „u siebie”. Bogactwa i luksusy, umizgi bogatych i wpływowych mężczyzn ją męczyły, a gdy już z bogactwa zostało niewiele i gdy zarabiała na życie malowaniem (cenionych przez krytyków) obrazów, nadal czuła, że jej życie jest jałowe. Nie mogła zapomnieć o tym, że jest Żydówką, że między nią a otaczającym ją światem zamożnych, wykształconych, „czystych" ludzi jest mur nie do przebicia, że nie będzie mogła się nigdy związać z nie-Żydem, a z Żydem najpewniej by nie chciała. Dzieciństwo spędzone w getcie siedziało w niej i nie chciało wyjść, domagało się swojej sprawiedliwości. Męczyło ją do czasu, aż pogodziła się ze swoim pochodzeniem i przeznaczeniem. Ale jeszcze przed pierwszą wizytą w rodzinnym miasteczku, gdy walczyły w niej sprzeczne uczucia, podczas pożegnania ze świeżo poznanym hrabią Litwickim, jej późniejszym kochankiem, z wyrzutem, złością i jednocześnie nutką satysfakcji przyznała się do swojego pochodzenia:

A moje nazwisko Grünszpann. Trzeba, aby pan to wiedział. Rojza Grünszpann. [...] Córka nędzarza z ghetta, Szlojmy - drogi panie - z tego oto miasteczka, do którego dojeżdżamy.

- Co mnie to wszystko obchodzi! Pani jest piękna - wybuchnął Litwicki.

- Tak, drogi panie - już byli nawet amatorzy na tę żydowską, nędzarską, rojzelowatą piękność (Alberti 1931: 169).

W rodzinnym domu nie mogła znaleźć sobie miejsca, denerwowały ją zabobony, brud i bieda. W jednym z ostatnich czynów Szlojmy, który to dawał swojemu najmłodszemu dziecku na przemian niedopity przez siebie rosół i mleko wraz z gruźliczą plwociną, nie widziała aktu ojcowskiej miłości, ale głupotę; w przesądach, odczarowywaniu, niezrozumiałych dla niej obrzędach nie potrafiła dostrzec - może i pojmowanej w niewłaściwy sposób - troski. Dopiero później

86

Fabrica Litterarum Polono-Italica | 2019, nr 1 (1) 
starała się zrozumieć tę żydowską pokorę, rezygnację, poddanie się woli Boga. Nie udało się jej to, ale przynajmniej zaczęła odczuwać litość, a wraz z nią przyszło poczucie misji.

Kobiece postaci znalazły swoje „odbicie” w typach męskich, nieraz wyrazistszych niż one same, choć zajmujących jeszcze mniej uwagi Alberti. Osobą, która zatrzymała się w pół kroku, była za słaba, by walczyć o swoje lub postarać się żyć z piętnem odrzucenia, czyli męskim odpowiednikiem Karolci Kurkówny, był jej mąż - Franciszek Rumiszewski. Rozdarty między chęcią zmiany a mieszczańskimi wartościami i przyzwyczajeniami. Uciekł z domu jako osiemnastolatek, by studiować medycynę w Szwajcarii, ale gdy na świat przyszedł jego syn, odezwała się w nim „mieszczańska krew”, potrzeba pójścia utartą ścieżką; zapragnął więc założyć własną praktykę, zapewnić rodzinie „godny byt”. Zatrzymał się, zastygł, nie był w stanie się ruszyć, nawet gdy widział, jak źle jego rodzina traktuje Karolinę. Samobójstwo żony powinno nim wstrząsnąć, zmusić do jakiegoś ruchu, ale był na to już za słaby, w pełni poddał się zniewalającej i odbierającej chęć do życia mocy cioci Klimusi, wydostał się spod niej wiele lat później, dzięki córce. Ale wyrzuty sumienia, poczucie długu wobec żony męczyły go cały czas. Dlatego też bez słowa pomagał Helenie we wszystkim, o co poprosiła, odbierał to bowiem jako zadośćuczynienie, gdyż w córce widział wierne odbicie Karolci.

Z kolei historia profesora Tomasza Gnieciucha poniekąd przypomina dzieje Róży. Z tą różnicą, że Gnieciuch wydaje się od niej silniejszy, bardziej konsekwentny, odporny - przynajmniej przez większość czasu - na zawołania „chłopskiej duszy”. Wydostał się ze środowiska chłopskiego tylko dzięki swojej ciężkiej pracy. Zawsze był najmniejszy i najbardziej chuderlawy ze wszystkich dzieci, cierpiał z tego powodu nie tylko w szkole, ale też w domu - ojciec bił go niemal codziennie; często też bywał głodny, zmarznięty, brudny, nie miał co na siebie włożyć. Wyróżniał się jednak uporem, siłą woli i nieprzeciętną inteligencją tak bardzo, że wiejski proboszcz postanowił opłacić mu naukę, pod warunkiem że Gnieciuch zostanie księdzem. Gdy jednak okazało się, że Tomasz ma inne plany, duszpasterz wyrzucił go z plebanii i przestał wspierać. Ale także tym razem przyszły doktor medycyny sobie poradził. Jego kariera rozwijała się w oszałamiającym tempie, w wieku czterdziestu lat uzyskał tytuł profesora...

Wszystko układałoby się świetnie, gdyby nie to, że - tak samo jak wielu bohaterów w powieściach Alberti - otoczony był niewidzialnym, ale niemożliwym do rozbicia murem ${ }^{22}$ i chyba bardziej nieprzyjemnym niż w innych wypadkach, ponieważ był to mur śmiechu. Chociaż Gnieciuch był wybitnym specjalistą w swojej dziedzinie, budził powszechną wesołość. Z jednej strony ze względu na swoją aparycję (bardzo niski wzrost, szeroką szczękę, wystające zęby, krzywe nogi), z drugiej:

22 Także i tutaj widoczne są inspiracje twórczością Zofii Nałkowskiej.

87

Fabrica Litterarum Polono-Italica | 2019, nr 1 (1) 
z powodu nazwiska nie tylko śmiesznie brzmiącego i mającego zabawne konotacje, ale odkrywającego też chłopskie pochodzenie bohatera. Tomasz zdawał sobie z tego sprawę, poczucie krzywdy starał się nawet złagodzić ironią i dystansem:

Ludzie rodzą się z jakimiś etykietami, które przylepione do nas trwają całe życie. Jedni się rodzą z marką dostojności, powagi, która nakazuje szacunek, inni ze stempelkiem śmieszności, którego zedrzeć nie można. Ja właśnie należę do tych drugich (Alberti 1937: 272).

Tylko Róża potrafiła zrozumieć profesora, i tylko jemu mogła bez skrępowania opowiedzieć całą swoją historię, ich przyjaźń była głęboka, bo oboje wyrośli na tych samych podstawach, byli rodzeństwem w nędzy, ludźmi z "tego samego dna”, połączyło ich niezrozumiałe dla ludzi spoza tego kręgu pokrewieństwo:

Jego dzieciństwo: to sen za dymnym piecem - zimą, w ostrej słomie - latem, to kradziona marchew, to brak koszuli, to owijanie nóg w śmierdzące onuce ojca [...]. Jej dzieciństwo: to cuchnąca izba, to ogonek śledzika objadany łapczywie, to potworne, czarne przesądy, to podwórko zachlastane pomyjami. [...] Wydostali się w inny świat: on wygryzł sobie drogę swojemi chłopskimi zębami, ona dostała się w ten świat przypadkiem. Oboje chcieliby żyć w tym świecie, ale tamto pierwsze było silniejsze, więc nie mogą (Alberti 1937: 287).

Wyjątkowym bohaterem na tle już tutaj pokrótce przywołanych był Bogdan Goldoński, nazywany przez bliskich Boczem. Ten młody, zaledwie dwudziestoletni gruźlik cierpi nie tyle z powodu choroby, ile z poczucia rozdwojenia duszy. Właściwie to ta niepewność co do swojej tożsamości, nienawiść skierowana przeciwko sobie tak osłabiły organizm Bocza, że panowanie nad nim objęła choroba. Goldoński był mieszańcem, wyklętym zarówno przez pobratymców matki, jak i ojca.

Elżbieta z Rutkowskich Goldońska, matka bohatera, była katoliczką, a jego ojciec Leo Gold - Żydem, który na prośbę ukochanej przyjął chrzest, spolszczył imię i nazwisko. Boczo więc, jako dziecko odrzuconej przez katolicką społeczność kobiety i wyklętego przez współwyznawców mężczyzny, jako odszczepieniec nie mógł nigdzie - nie z własnej winy - znaleźć miejsca. Największym problemem była dla niego płynąca w jego i jego siostry żyłach krew żydowska, a co za tym idzie charakterystyczny, łatwo rozpoznawalny wygląd, który powodował, że „czyści, biali” koledzy śmiali się z niego i wytykali go palcami. A pamięć o tym, że jest synem „wychrzty”, sprawiała, że bogobojni chasydzi spluwali za nim, szepcząc pod nosami niezrozumiałe słowa.

Choć Boczo starał się pozbyć oznak „„żydostwa”: wygładzał kręcone włosy, starał się inaczej patrzeć, chodzić, mówić, śmiać się (Alberti 1937: 312-313), zawsze w szko-

88

Fabrica Litterarum Polono-Italica | 2019, nr 1 (1) 
le postrzegano go jako Żyda. Zawsze był naznaczony ${ }^{23}$. Pałał nienawiścią do swojego wyglądu, do swojego ciała, poddał się chorobie, by zniszczyć to, co przez ostatnie dwadzieścia lat go męczyło. Pomieszana, a według samego bohatera nieczysta krew powodowała, że czuł się rozszczepiony na dwie niechcące się z sobą pogodzić połowy (Alberti 1937: 306). Nie był związany ani z kulturą matki, ani z kulturą ojca, ale przez społeczności miasteczka i getta wpychany był w rolę „wychrzty”, a więc człowieka znajdującego się „pomiędzy”24, postrzegany zawsze jako nie-swój, obcy, nigdzie niepasujący. Pragnął, by ktoś go jednoznacznie określit, by pozwolono mu być nawet członkiem tej znienawidzonej przez siebie żydowskiej wspólnoty, bo wtedy wreszcie odzyskałby spokój:

Wtedy byłoby wszystko równe we mnie. Nie byłbym rozszczepiony, podwójny. Miałbym przed sobą jeden kierunek. A nade wszystko wiedziałbym, po której stronie życia mam żyć. Miałbym przed sobą otwartą drogę do społeczeństwa żydowskiego. A tak - ci mną gardzą, bo odstąpiłem od nich, a ci mnie nie chcą przyjąć, bo nie jestem "rdzenny”, "rasowy”, „stuprocentowy” (Alberti 1937: 312).

Odrzucony przez wszystkich, nie chciał upodabniać się do wyśmiewających go chłopców - od razu, jak sam mówi, stał się dorosły. Nie przechodził normalnie okresu dojrzewania, nie miał - co istotne dla fabuły powieści - żadnych kontaktów z kobietami. Pogrążając się w nienawiści do siebie i otoczenia, zaczął też wpadać coraz głębiej w "nałóg” wysysający z niego siły życiowe - onanizm (Alberti 1934a: 332-334). Ze wszystkich tych przypadłości skutecznie, dość niekonwencjonalnymi metodami, wyleczyła go Helena - własnym kosztem. Przemiana tragicznego, rozdwojonego bohatera w pogodzonego ze światem i - co ważniejsze - ze sobą młodego mężczyznę dokonała się szybko, nie została przez autorkę szczegółowo opisana ani umotywowana. Wskazała ona jedynie na pewne pokrewieństwo dusz Heleny i Bocza, na "spadek wykluczenia”, który Helenie dał tak dużo siły, że mogła uratować znajdującego się najgłębiej w piekle odrzucenia, bo niechcianego też przez samego siebie, Bogdana.

23 Por.: „Gdy Boczo mówił - bardzo żywo, nerwowo gestykulował rękami. Była to wymowa tej starej rasy, która na jego twarzy wypisała swoje tajemnicze znaki: »każdy cię rozpozna wśród tłumu« (Nie wiadomo tylko, czy jest to zaszczyt odrębności, czy piętno: »jesteś naznaczony«)" (Alberti 1937: 298-299).

24 Por. wizerunek przechrztów w Nie-Boskiej komedii Zygmunta Krasińskiego. Matka Bocza niejednokrotnie podkreśla, że zmuszenie Leona do przyjęcia chrztu było błędem, skazała go tym samym na ostracyzm (Alberti 1937: 380-381).

89

Fabrica Litterarum Polono-Italica | 2019, nr 1 (1) 
Wszystkie powyższe historie, co łatwo zauważyć i co niejednokrotnie już sygnalizowałam, są nie tylko schematyczne, ale też pisane z podobnej perspektywy. Mamy do czynienia z różnymi bohaterami, którzy powinni przemawiać odmiennymi językami, tymczasem w słowach Karolci, Róży, Heleny, Tomasza, Bocza (Franciszek prawie w ogóle nie był dopuszczony do głosu) i narratorki pobrzmiewa ta sama nuta.

Mówiąc o obrazie odrzuconych w twórczości Kazimiery Alberti, nie można zapominać, że jej pacyfistyczne przekonania, wrażliwość na krzywdę ludzką widoczne są w każdym niemal fragmencie tekstu: w doborze słów, środków stylistycznych, w obrazowaniu, w nazbyt częstych komentarzach i wyjaśnieniach autorki. Pisarka wszystkie opisywane przestrzenie, wszystkie kręgi odrzucenia „przepuszcza przez siebie”, przez swoje doświadczenia i przemyślenia, co w tym wypadku zostawia wyraźny ślad w tekście. Najbardziej przejmujące i przekonujące, najlepiej napisane, choć niewolne od stereotypów i dalekie od obiektywizmu, są opisy miejsc i grup społecznych, które sama zbadała, w których przebywała. Jednym z nich jest getto, drugim - niebędące tutaj głównym przedmiotem zainteresowania - mieszkanie tzw. porządnej, mieszczańskiej rodziny.

Dla Alberti nędza jest jednakowa, jednakowi są też nędzarze. Mieszkańcy trzech pierwszych kręgów odrzucenia wyglądają w omawianych tekstach podobnie. Są zwykle w jakiś sposób ułomni lub chorzy: bardzo niscy, krępi (robotnicy z Wiecu robotników, Tomasz Gnieciuch), z brodawkami na rękach (brat Róży), cierpiący na suchoty (Szlojma, Boczo), czarni (Żydzi, robotnicy) ${ }^{25}$, „pełni plam wątrobianych, żylaków i sińców" (robotnicy z Wiecu, Szlojma, Klara), śpią w zatłuszczonej i brudnej pościeli (Żydzi, chłopi), chodzą w „zatłuszczonych kaszkietach” (robotnicy z Czerwonej wiosny), perukach lub brudnych, po raz kolejny - za Alberti - użyję tego słowa: zatłuszczonych właśnie, ubraniach (Żydzi z getta, robotnicy z Czerwonej wiosny),

25 Warto zauważyć, że czerń - atrybut nędzarzy, rozciąga się też w tekstach Alberti na bogatych Żydów („czarna giełda”, „czarny kapitał”), oznaczając tym samym ich nędzę moralną. Sam kolor budzi przecież zdecydowanie negatywne konotacje, jest „symbolem zła, niemoralności, przesądów, strachu, ponurości, uporu, zmartwienia, nienawiści, niebezpieczeństwa, ohydy, oszustwa, tragedii, katastrofy, zniszczenia, smutku" (Kopaliński 2001: 48). Ciekawie wypada porównanie tej żydowsko-nędzarskiej czerni z czernią Afroamerykanów i jej percepcją w tamtejszej kulturze: „Można powiedzieć, że generalnie w białej kulturze Zachodu to, co czarne, i to, co złe, stały się synonimiczne. W świadomości białego człowieka czarni nosili bardzo wyraźne stygmaty ofiarnicze, odbierane jako desygnat wszystkich wartości negowanych przez białą kulturę. Stygmatem był tu sam kolor skóry, który budził pogardę, ale też lęk i poczucie zagrożenia. Tak jak w Europie żyd odbierany był jako archetyp czarownika i nosiciel złych mocy, tak w społeczeństwie amerykańskim to, co diabelskie, utożsamiał "Murzyn«" (Domańska 2008: 101). Czerń zresztą przypisywana była dość powszechnie w kulturze ludowej (w tym polskiej) złu i mocom nieczystym, zagrożeniu, ewentualnie niepełnosprawnościom czy chorobom. Por. Benedyktowicz 2000; Bystroń 1995; Stomma 1986.

90

Fabrica Litterarum Polono-Italica | 2019, nr 1 (1) 
ich twarze są „pełne sińców” (robotnicy, Boczo), „szare jak pergamin” (robotnicy) lub żółte (Szlojma).

Opis nędzy zamyka się więc w czterech kolorach: czarnym, sinym/fioletowym, szarym i żółtym, w łatwo zauważalnych oznakach chorób oraz tłuszczu, który kojarzy się z brudem, lepkością, czymś, czego nie da się zmyć. Lepkość tłuszczu przenosi się też na metaforyczny obraz getta/wiejskiej chaty/robotniczych mieszkań - te miejsca brudzą bowiem swoich mieszkańców: brud czepia się ich, jest nie do usunięcia.

Każdą z grup, którymi zajmowała się Alberti w swoich tekstach, charakteryzują też pewne stałe cechy i zachowania, będące częściami obecnych od dawna w polskiej kulturze stereotypów, mowa jest więc w książkach bialskiej pisarki o „chłopskiej ambicji”, „twardych zębach”, którymi Gnieciuch „wygryzł sobie” drogę do awansu społecznego, ale też „chłopskiej zawiści i zazdrości”, będącej przyczyną zakupu wielkiej willi przez Tomasza; pojawiają się „żydowska pokora” i „żydowski stoicyzm”, ale też „żydowska zabobonność”; robotnicy również nie są wolni od stereotypowych zachowań i cech: są hardzi, uparci, nigdy nie płaczą - nawet gdy ich jedyne dziecko wyjeżdża za granicę. Najciekawiej na tym tle wypadają Żydzi, najczęściej opisywani bohaterowie tekstów Kazimiery Alberti ${ }^{26}$.

Bialska autorka, gdy pisze o getcie, nie może się wydostać spod wpływów nie tylko wielkich poprzedników, zwłaszcza Elizy Orzeszkowejej, ale też stereotypów. I choć bardzo wnikliwie zbadała getto, rozmawiała z mieszkańcami, poznała język, księgi ważne i święte ${ }^{28}$, starała się zrozumieć to, co nazywa „duszą żydowską”, zatrzymała się na powierzchni. Nie tylko nie została dopuszczona do środka badanej społeczności, ale - jak się wydaje - wcale tego nie chciała. Świat żydowski widziała jedynie w czerni i bieli, a przynajmniej taki jego obraz przedstawiła w powieści: jest to albo biedne, trwające mimo wszystko, getto gdzieś w Rzeczpospolitej, albo zamknięta, głucha na błagania i prośby o pomoc, kasta grubych, zepsutych „żydowskich kapitalistów"29, mająca, jeśli nie władzę nad światem, to przynajmniej liczne w nim koneksje. Róża w rozmowie z profesorem Gnieciuchem mówi:

26 Alberti napisała również tom wierszy stylizowanych na piosenki żydowskie, o czym mówiła w jednym z wywiadów: „[...] ci ludzie getta, których poznałam i pokochałam, szli za mną krok w krok, dopraszając się wiersza [...]. I oto powstał właśnie zupełnie świeży ton poezyj pt. Piosenki żydowskie. Uważam, że nie ma jeszcze takich w literaturze polskiej. Użyłam świadomie prostych rymów, odtwarzając proste, jak nędza przeżycia, bez metafor" (Alberti 1934b).

27 Wpływ innych pisarzy widoczny jest też, gdy pisze o robotnikach (Żeromski) i chłopach (Kasprowicz, Konopnicka).

28 „Wojnę i ghetto uważam za największe, bolesne rany XX wieku. Powieści tej poświęciłam wiele pracy przygotowawczej, studiując hebrajszczyznę, Pięcioksig̨g i szereg źródeł. Pisałam ją miesiąc, bez odrywania się, czasem bez zjedzenia obiadu" (Alberti 1930).

29 „A przecież gdzieś tam na świecie w stolicach i większych miastach pasły się i zaokrąglały brzuchy żydowskich paskarzy. Och! te czerwone pyski, wyglancowane dobrobytem! [...] cały ten zatęchły, robaczywy, kuplerski światem, który zrodziła i wyhodowała wojna. O wojno! Jak-

91

Fabrica Litterarum Polono-Italica | 2019, nr 1 (1) 
Wiesz, gdy czasami myślę o tych tu sprytnych żydach z giełdy, z banków, ze sklepów, z przedsiębiorstw, o tych dostawcach, eksporterach, o całym tym świecie wielkich interesów, oszustw, fałszerstw, zmyślonych plajt, podstawionych faktorów, nieprawnych kontaktów, fałszowanych weksli, czeków, podpisów, o tym świecie czarnego wyzysku, kłamstwa, hochsztaplerstwa, zagrabionych spadków, intercyz, licytacyj, importu - doprawdy zimno się mi robi. Och! jakże ja żydówka nienawidzę tego tak zwanego „żydowskiego kapitału" - tej czarnej, pieniężnej międzynarodówki, tego impertynenckiego stukotu złota. Tej rzeki, co się przelewa przez krótkie, grube, bankierskie paluchy zorganizowanej, silnej kasty żydowskich posiadaczy, tego zespolonego muru, ciągnącego się bez wyrwy przez wszystkie kraje świata, muru, przed którym schylają głowy najgłębsi politycy, najwięksi dyplomaci, premierzy, ministrowie! (Alberti 1934a: 291).

Z jednej więc strony mamy opis przerażającej biedy, skrajnego ubóstwa, z drugiej - świat bogatych kapitalistów, złych i nieuczciwych, tak bliski obrazom zbyt często obecnych w antysemickiej, skrajnie prawicowej prasie okresu międzywojennego. To przedziwne połączenie filo- i antysemityzmu można chyba wytłumaczyć tylko (czy planowaną?) dydaktyczną i prostą wymową całości utworu. Wrażliwość na krzywdę najbiedniejszych, często powtarzane rozważania nad niesprawiedliwością społeczną, pytania retoryczne kierowane nie tyle do Boga, ile do czytelników, filosemityzm - wszystko to podszyte jest stereotypem. Wystarczy bliżej przyjrzeć się opisom getta i jego mieszkańców, opisom, owszem, pełnym współczucia (czy napisanym tak, żeby współczucie wywołać): są to naturalistyczne, mocne, świetnie napisane fragmenty - aby wyczuć w tych opisach, czyli w głosach bohaterów i narratorki / autorki, nutę wyższości czy protekcjonalności.

Wydawałoby się, że rozdarty między dwoma światami Boczo chciałby do któregoś z nich należeć, ale jego zapewnienia nie wydają się szczere. Jego wcześniejsze, pełne niechęci i pogardy uwagi na temat chłopców z klasy, ludzi z miasteczka czy miejscowych Żydów (też: krwi żydowskiej, której się wypiera), wyraźne deklaracje, że nienawidzi zarówno katolików, jak i Żydów (Alberti 1934a: 321), to, że tylko on dotarł - choć, jak podkreślam, nie z własnej woli - do najwyższego punktu odrzucenia (przez Żydów, katolików, kolegów, nawet po części przez matkę, która nie potrafiła go zrozumieć, w końcu przez samego siebie), wyróżnia go, dodaje mu nie tylko cech tragicznych, ale też poczucia wyższości. Boczo czuje jakąś więź wyłącznie ze swoją siostrą - takim samym mieszańcem jak on:

że wyszlachetniasz ludzi! A z drugiej strony te Surcie i Matle, stojące od świtu »w ogonach", pod murem za kawałkiem chleba, wypieczonego z kukurydzy, popiołu i bobowej mieszanki" (Alberti 1931: 64).

92

Fabrica Litterarum Polono-Italica | 2019, nr 1 (1) 
Hanię lubię, choć nie umiem jej nazwać. Ona jest jakaś [wspólna - K.P.], najbliższa krewna - uśmiechnął się boleśnie - taka, jak ja - mieszana, podwójna.

- Więc nie matka?

Zamyślił się długo.

- Nie. Matka jest dalsza krewna. Ona jest pełna, nie ma krwi złożonej, jest stuprocentowa. A we mnie i w Hani walczą dwie rasy, dwie koncepcje życiowe, dwa różne kierunki. Niepokój, dynamika rasy żydowskiej, która gna człowieka z miejsca na miejsce, od przeżycia do przeżycia, od celu do celu i statyka rasy aryjskiej. Hania jest bliższa (Alberti 1934a: 320).

Częściej jednak, zwłaszcza w ustach Róży, pojawiają się komentarze pełne współczucia, próby zrozumienia żydowskiej społeczności. Ale zrozumienie to może być tylko połowiczne, bo nie wychowała się w tradycji i w obyczajach kultywowanych w getcie, zapomniała tak wiele, że może na modlących się Żydów patrzeć tylko z litością, pobłażaniem lub współczuciem. Jednak zawsze będą to litość, pobłażanie i współczucie człowieka wykształconego, czystego, który nawet jeśli pochodzi ze świata, o którym mówi, to znajduje się już poza jego nawiasem, „zaraża się" (por. Waldenfels 2002: 4) - wtórnie - obcością od niegdysiejszych swoich, nie należy już do nich:

Teraz, gdy chodzili na groby, gdy się w synagodze modlili z pokorą, strachem i rozpaczą - odczułam w nich ludzi. Ludzi słabych, którzy muszą się o jakąś siłę wyższą oprzeć - bo sami bez tych modlitw, postów, trąbienia, śpiewu, czyli bez tego całego oparcia - upadliby. Zastanawiałam się nad tem [...] - czy mogłabym przyjąć jakąkolwiek religię. I doszłam do przekonania, że absolutnie nie. Zanadto wierzę w siły, w moc, w trud człowieka - abym mogła uwierzyć w Boga. Religią jest mi moje własne serce. Najwyższem światłem i najprostszą drogą. Busolą, drogowskazem i masztem (Alberti 1931: 299).

\section{Bibliografia}

AlBeRTI Kazimiera (1930): Godzina rozmowy z Kazimierq Alberti. "Gazeta Lwowska” 29.11.

Alberti Kazimiera (1931): Ghetto potępione. Opowieść o duszy żydowskiej. Warszawa. AlberTI Kazimiera (1934a): Ci, którzy przyjdq. Powieść mieszczańska. Warszawa. AlBeRTI Kazimiera (1934b): Godzina z poetkq. „Gazeta Poranna” 19.02.

AlBERTI Kazimiera (1937): Więcierz w głębinie. Warszawa.

[B.a.] (1934): K. Alberti: Ci, którzy przyjdq. [Rec.]. „Robotnik” 25.06.

93

Fabrica Litterarum Polono-Italica | 2019, nr 1 (1) 
BENEDYKTOWICZ Zbigniew (2000): Portrety "obcego": od stereotypu do symbolu. Kraków.

BYSTROŃ Jan Stanisław (1995): Megalomania narodowa. Warszawa.

CzACHOWsKı Kazimierz (1931): K. Alberti: "Ghetto potępione”. [Rec.]. „Lwowskie Wiadomości Muzyczne i Literackie" 6.05.

DoMAŃSKA Aleksandra (2008): Obcy jako kozioł ofiarny, percepcja czerni w kulturze amerykańskiej. W: Cieliczko P., Kuciński P., red.: Literackie portrety Innego. Inny i Obcy w kulturze. Cz. 2. Warszawa.

GolEC Józef, BoJdA Stefania (1995): Słownik biograficzny Ziemi Cieszyńskiej. T. 2. Cieszyn.

HIRSzHORN Samuel (1931): Śladem Elizy Orzeszkowej. „Nowy Przegląd”, nr 66.

KŁAK Tadeusz (1962): Słowo o Kazimierze Alberti. „Tygodnik Powszechny”, nr 50.

KOPALIŃSKI Władysław (2001): Słownik symboli. Warszawa.

MAgIERA Halina (2010): Od popularności do literackiego niebytu. „Bielsko-Żywieckie Studia Teologiczne", T. 11.

MILIKIEWICzoWa Maria (1931): Pełny człowiek. „Kurier Wileński” 8.05.

[M.K.] (1931): Powieść autorki polskiej o „duszy żydowskiej”. „Nowy Dziennik” 30.03.

Mniszkówna Helena (1972): Trędowata. Powieść. T. 1. Kraków.

NegtSAB Najcul (1934): Na marginesie powieści mieszczańskiej: „Ci, którzy przyjdq” Kazimiery Alberti. „Zjednoczenie Śląskie” 8.07.

PODHORSKA-OKOŁów Stefania (1931): Kazimiera Alberti: „Ghetto potępione”. [Rec.]. „BluszCZ” 18.07.

RADWAŃSKA-PARYSKA Zofia, PARYSKI Witold Henryk (1995): Wielka encyklopedia tatrzańska. Poronin.

ROSNER Edmund (1982): Przypomnienie Kazimiery Alberti. W: Idem: Beskidzkie ścieżki pisarzy. Katowice.

StommA Ludwik (1986): Antropologia kultury wsi polskiej XIX wieku. Warszawa.

STRYJKOWSKI Julian (1979): Austeria. Warszawa.

WALDENFELS Bernhard (2002): Topografia obcego. Przeł. J. Sidorek. Warszawa.

WYLĖ̇Ý́SKA Aurelia (1934): W Polsce - u pani starościny. „Bluszcz”, nr 2.

\section{Abstract}

\section{"Signori nella miseria"}

o il racconto di Kazimiera Alberti riguardo gli emarginati

L'articolo si concentra sulla descrizione, presente in quasi tutte le opere di Kazimiera Alberti tra le due guerre, dell'analisi letteraria dei problemi sociali. Ciò che è evidente in questo lavoro è la "gerarchia" delle persone che soffrono per le disuguaglianze sociali, economiche, etniche o legate al sesso. Questa "gerarchia" può essere paragonata ai gironi dell'inferno, sebbene in questo caso il livello della sofferenza non dipende dai peccati commessi ma dal grado di rifiuto della società. L' Alberti colloca

94

Fabrica Litterarum Polono-Italica | 2019, nr 1 (1) 
gli ibridi culturali ed etnici nel più profondo cerchio dell'inferno - sono visti come stranieri (e spesso non come esseri umani) da entrambe (o più) culture / comunità da cui provengono.

Parole chiave: Kazimiera Alberti, letteratura polacca tra le due guerre, straniero/altro, rifiuto, problemi sociali, ibrido culturale 